\title{
Autobiographical Elements In Dickens's David Copperfield
}

\author{
SumeraSubuhi \\ Research Scholar, Department of EnglishSri SatyaSai University of Technology and Medical sciences \\ Sehore, Madhya Pradesh
}

\begin{abstract}
Charles Dickens could never dissociate himself from the remembrances of the heartrending experiences of his childhood.The early novels of Dickens were an attack on the harsh Victorian society. He portrayed a realistic picture of the brutalities prevalent during the era. The later novels on the other hand were subjective in tone. Even though Dickens's own experiences provided the necessary information for the plots of his works, yet the two most autobiographical novels are David Copperfield and Great Expectations.
\end{abstract}

Key Words-Childhood, Memory,Agony, Suffering,Autobiographical

Dickens's childhoodwas full ofadversities. The distress and anguish he underwent caused great trauma to the youngchild, which lasted long in his life. The agony of the heart-rending experiencesstayed with him forever and even after gaining success in life he could not dissociatehimself from them.Dickens's pain intensified when he saw his parents unaffected and indifferent to his plight. He always dreamt of acquiring education but here he could see his dreams being shattered. Dickens was always an avid reader and from early childhood started exploring the little library of his father which comprised of many classics. As he was a feeble boy and often fell ill could not indulge in external activities. The regular attacks of spasm prevented him from participating in active exertion. Even though he could not play himself, yet he took great pleasure in observing other boys. His photographic memory which was aided by strong imagination provided ideas which he used later in his career. The sickness proved to be a blessing in disguise the greatest advantage being his strong inclination towards reading. Suddenly everything in the young boy's world got topsy-turvy and he was terribly shaken. He could not sink in the fact that his parents agreed to send him to work. He told John Forster, "It is wonderful to me how I could have been so easily cast away at such an age. It is wonderful to me, that, even after my descent into the poor little drudge I had been since we came to London, no one had compassion enough on me - a child of singular abilities, quick, eager, delicate, and soon hurt, bodily or mentally - to suggest that something might have been spared, as certainly it might have been, to place me at any common school Our friends. I take it, were tired out. No one made any sign. My father and mother were quite satisfied. They could hardly have been more so, if I had been twenty years of age, distinguished at a grammar-school, and going to Cambridge"(201).

The agony was immense as his means were extremely limited, inadequate for a square meal for the entire week. He confessed to Forster, "I know I do not exaggerate, unconsciously and unintentionally, the scantiness of my resources and the difficulties of my life. I know that if a shilling or so were given to me by anyone, I spent it in a dinner or a tea. I know that I worked, from morning to night, with common men and boys, a shabby child"(210).He acquired good mannerisms since early childhood which was polished even more by the extensive reading. Dickens's language and behaviour was way different from his colleagues at the factory. He was just twelve years of age yet could not reconcile himself with the surroundings he was dumped into by his parents. For him there was no hope of getting respite from the menial job. The agony of being victimized by the harsh Victorian society was unendurable for the young heart which was further intensified by the wretched working conditions. He suffered while working but the biggest irony of his fate was that those who were instrumental in shattering his world remained indifferent. His sufferings were beyond the imagination of people around him. The trauma of neglection from parents and his shattered dreams filled the days of Dickens with disgust and gloom. He could foresee the roads to success coming to an end. Hopelessness engulfed young Dickens and the saddest part was there was no ray of hope at this point. He confessed to Forster, "My rescue from this existence I considered quire hopeless, and abandoned as such, altogether; though I am solemnly convinced that 
I never, for one hour, was reconciled to it, or was otherwise than miserably unhappy. I felt keenly, however, the being to cut off from my parents, my brothers, and sisters; and, when my days work was done, going home to such a miserable blank; and that, I thought, might be corrected"(212).

There was a stroke of luck in John Dickens's life and he inherited a small legacy of a relative which was instrumental in letting him out of Marshalsea. The family then shifted from the debtor's prison to lodge with Ms.Roylance in little cottage street. The family's reprieve from the ordeal made no difference to Dickens as his parents provided no solace to him, none thought of acquitting the young boy from his job. It was on one occasion that his father quarreled with the owner of the factory, and Dickens was withdrawn from there. His mother disapproved of the decision and set herself to settle the quarrel. But destiny favoured the young boy this time and his father rejected. This attitude of hismother affected him adversely and the relationship between them became restrained, he confessed to Forster, “...I never after words forgot, I shall never forget, I never can forget, that my mother was warm for my being sent back"(216).

The humiliation and distress he was subjected to by his parents had entrapped him firm when on one occasion he witnessed his sister, Fanny, receive a prize at the Royal Academy of Music. He told Forster, "I could not bear to think of myself...beyond the reach of all such honorable emulation and success. The tears ran down my face. I felt as if my heart were rent. I prayed, when I went to bed that night, to be lifted out of the humiliation and neglect in which I was. I never had suffered so much before. There was no envy in this" (219).He became even more aware of his own ignominy.

Dickens's education was resumed at The Wellington House Academy in North London, where he remained for nearly two years. The harm to the innocent mind had already been done as those experiences were endorsed permanently; the outcome was a complete wreck in his basic nature. The close encounter with the seamy side of the world gave birth to the philanthropist Dickens; the world later came to know. His compassion towards the victims of child-labour has its roots in his own dark days spent in the blacking factory, where his best and worst feelings were alike. The righteous anger stemming from his own situation and the conditions under which working-class people lived became major themes of his works.

Dickens's Journalism which primarily comprised of reporting of Parliamentary debates, coverage of election campaign, for which he traveled across Britain, for the Morning Chronicle. Later his collection of journalism formed his first independent work, Sketches byBoz.Boz was the nick name which was adopted by Dickens. From here these was no looking back for Dickens.

Charles Dickens could never dissociate himself from the remembrances of the heart-rending experiences of his childhood. The anguish kept surfacing and referring to those days Dickens wrote to Forster,

No words can express the secret agony of my soul as I sunk into this companionship; compared everyday associates with those of my happier childhood; and felt my early hopes of growing up to be a learned and distinguished man crushed in my breast. The deep remembrances of the sense of I had of being utterly neglected and hopeless; of the shame I felt in my position; of the misery it was to my young heart to believe that, day by day, what I had learned and delighted in, and raised my fancy and my emulation up by, was passing away from me, never to be brought back any more; cannot be written. My whole nature was so penetrated with grief and humiliation of such considerations than even now famous and caressed and happy often forget in my dreams that I have a dear wife and children; even that I am a man; and wander desolately back to that time of my life"'(220)

For years Dickens kept the most distressful aspect of his life to himself, as he did not divulge it to anyone, accidentally some of the truth was revealed to John Forster. Later on, Dickens unfolded his life to him, his friend and biographer. Dickens began his career as political journalist therefore used his novels to examine the problems he saw in the society. The early novels of Dickens were an attack on the harsh Victorian society. He portrayed a realistic picture of the brutalities prevalent during the era. The later novels on the other hand were subjective in tone. Even though Dickens's own experiences provided the necessary information for the plots of his works, yet the two most autobiographical novels are David Copperfield and Great Expectations.

The specialty of David's character is in the fact it was closest to its creator's, Dickens, heart. In the preface of the book, Dickens remarks: Of all my books, I like this the best. I will be easily believed that I am fond parent of every child of my fancy. . . . But, like many fond parents, I have in my heart of hearts a favourite child. And his name is David Copperfield.(6) 
David Copperfield tells the story of a young boy battling against the hostile forces and maturing through a series of trials. It mirrors the struggles, sufferings and achievements of Dickens himself. Accordingly to Hugh Walker, "The pen that wrote David Copperfield was dipped in his (i.e. Charles Dickens own blood." ${ }^{10}$ Through the novels Dickens purged the agony of his own neglected childhood; rather they were an attempt to awaken the Society from its slumber to the welfare of children.

David Copperfield, at the outset was shown leading a happylife in company of mother Clara and nurse Pegotty. His mother nurtured the child with warmth and affection and Pegotty too, took great care of the little boy. Her narration of bed time stories stimulated the mind of David. The haven of the young boy was the safest place for him until the encroachment of Mudstones. Clara married Mr. Murdstone, who moved in to stay with the family along with his sister. The two wretched havoc in the lives of the Copperfield. David became theirsoft target and Clara, helplessly witnessed the tortures her son was subjected to - "The influence of Murdstone upon me was like the fascination of two snakes upon a wretched young bud" (D.C. Ch. IV.)

David's interests were completely ignored by his step-father, who, along with his sister left no stone unturned to traumatize the young boy. He was regularly beaten, locked in solitude, kept away from his mother to name a few tortures the boy suffered. Their relentless behaviour and his mother's helplessness squared up to make David's life miserable.

The natural result of this treatment, continued, I suppose, for some six months or more, was to make me sullen, dull, and dogged. (D.C., Ch. IV.)The worst was still to come in David's life. His mother died while giving birth to a child. Now David was not frequently beaten or starved rather was 'Coldly neglected', his needs were ignored. Murdstone adopted a cold attitude which created turbulence in his heart and mind. $\quad$ "I was not actually ill-used. I was not beaten, or starved; but the wrong that was done to me had no intervals of relenting, and was done in systematic, passionless manner. Day after day, week after week, month after month."(David Copperfield Ch. X.)

Finally, David's education was disrupted and sent to work in a blacking factory. Both Dickens and David worked in the factory under duress which scarred them so profoundly that it remained the saddest chapter of their lives. Charles Dickens was victimized by his own parents whereas; David was plunged into the dark world of 'Child Labour' by his step father, Mr. Murdstone. The tender heart of the little boy was permanently braised; the agony of it kept surfacing time and againThe blacking factory was extremely dirty uncongenial and infested by rats. David worked almost ten to fifteen hours a day to earn six or seven shillings at the end of a week. The meagre amount was inadequate to fulfill the basic requirements of square meal and clothing. Whole day he was engaged in washing and labeling bottles. He led an extremely miserable life without any companion to provide solace to his wounded heart. David says,

I had no advice, no counsel, no encouragement, no consolation, no assistance, and no support, of any kind, from any one, that I can call to mind, as I hope to go the heaven." (David Copperfield, Ch. X.)He worked with ordinary boys and men, who possessed crude language and coarse mannerism. David's behaviour made him stand apart from the working class. Being friendless and forsaken by all, his worst and best feelings were alike. His nature was permeated with shame and humiliation.

I never said, to man or boy, how it was that I came to be there, or gave the least indication of being sorry that I suffered, it is, as utterly beyond my power to tell. But I kept my own counsel, and I did my work. I knew from the first, that, if I could not do my work as well as any of the rest, I could not hold myself above slight and contempt. I soon became at least as expeditious and as skillful as either of the other boys. Though perfectly familiar with them, my conduct and manner were different enough from theirs to place a space between us."(David Copperfield, Ch. X.)

The sufferings of David aggravated as the days passed by leaving him isolated and disgusted. "I mingled my tears with water in which I was washing the bottles; and sobbed as if there were a flaw in my own breast, and it were in danger of bursting." (D.C., Ch. XI)

It was when David's battling power surpassed his endurance; he decided to flee from the blacking factory. All his hopes rested upon Miss Betsy Trotwood, his aunt at Dover. Luck favoured the little boy this time and his aunt agreed to provide shelter and adopts him. After putting up with the adversities ever since his mother's remarriage, finally David found peace. He was loved and cared for and his education was re-started at Doctors Strong's school. Later he was apprenticed to Spenlow and Jorkin. He learned short hand and became a press reports at the court of the Doctor's Common. Finally, he too, like Dickens himself, became a parliamentary reporter. David's perseverance and resilience rewarded his success and thus fulfilling his childhood dream of 
acquiring good education and becoming a gentleman. Dickens presented details of his early life in the novel with only few minor changes. David is shown to be of eight years when sent to work in the blacking factory, whereas, Dickens was twelve. The lowering of the age intensifies the pathos in David's story. Dickens portrays David as a fatherless child and his mother a fragile individual. Dickens's own parents exposed him to the cruelties of the Victorian Society. Both Dickens and David became heir to the sins committed by their fathers. It was Dickens's own sense of isolation during the formative years which found it's outlet in David Copperfield and other works.

Mr. and Mrs. Micawber are true representations of Dickens's parents. John Dickens's reckless behaviour was represented throughthe character of Mr. Micawber. He too could never keep a balance between his earnings and expenditure, therefore was in perpetual debts. In an attempt to overcome absolute poverty both had to pawn household things and were never able to retrieve them back. The consequence of his shiftlessness and irresponsible attitude was imprisonment in Marshalsea Debtor's prison.

In David Copperfield there are numerous instances where the dramatic context might disguise their subjective origin. A sensitive reader can trace innumerable details, not major ones, in the novel - the education of David at Salem House Academy under the sadistic Mr. Creakle is a close parallel to Wellington House. Again, MrMicawber is undoubtedly JohDickens.In his works, Dickens reveals an implicit engagement with his character (the degree of involvement naturally. varies in different novels). In addition, he is genuinely concerned with materials of a more personal significance. In a letter dated October 1850, Dickens confesses:

"I am within three pages of the shore; and am strangely divided, as usual in such cases, if I were to say half of what Copperfield makes we feel tonight, how strangely, even to you, I should be turned inside out! "I seem to be sending some part of myself into the Shadowy World"(243)

After Dickens's death Forster printed enough of the fragment (the manuscript that Dickens himself "never meant to be published on any account"...) to disclose the well-kept secret that the wretchedness of David Copperfield at Murdstone and Grimsby's had it's close parallel in the novelist's own despair when he had been consigned as a child to Warren's blacking-warehouse.

Charles Dickens was well acquainted with the pain of being deserted by parents and traumatized by the external world. He did not have any companion to share his distressful condition David Copperfield too was entrapped ina similar situation. Though he had friendly relations with the Micawber family, he could never share his own grievances. The young David's heart moved at the plight of Micawbers.

"MrMicawber's difficulties wee an addition to the distressed state of my mind. In my forlon state I became quite attached to the fancily and used to walk about, busy with MrsMicawber's calculations on the ways and means, and heavy with the weight of MrMicawber's debts." (David Copperfield, Ch. XI)

The consequence of a distressed childhood continued even after he became famous and had a family. Despite the success, Dickens could never completely detach himself from the remembrance of those 'dark days' of his life. Perhaps he created the novel with the intention of sharing his agony with readers and undergoing a catharsis. Dickens, himself had lived the life of a fantasist. He had fantastic dreams in his childhood, which he had seen being shattered. If Dickens was successful in presenting a realistic picture of poverty, social disgrace, distorted childhood, trauma of parentless children, ignorance of parents and the agony of being unloved and unwanted it was because he had undergone it all. He had to struggle hard and pave a way for himself. The world in which he lived was very hard and cruel, as it was for countless other children. The picturebook image of a 'Romantic' child existed in the world of print. The actual nineteenth century world was heartless to the unfortunate members of society, and towards children in particular. The hostile society is repeatedly portrayed as are either orphans or abandoned by their parents.

\section{WORKS CITED}

[1] Ackroyd, Peter. Dickens: Public life and Private PassionHylas Publishing, 2002.Print.

[2] Dickens, Charles. David Copperfield. Hertfordshire: Wordsworth Editions Ltd, 2000. Print.

[3] ....Great Expectations. Hertfordshire: Wordsworth Editions Ltd, 2007. Print.

[4] Walker, Hugh. The Literature of the Victorian .London: Cambridge University Press, 1955.Print. 